\title{
Morphological and Ginsenoside Differences among North American Ginseng Leaves
}

\author{
John T. A. Proctor ${ }^{1 *}$, Alan J. Sullivan ${ }^{1}$, Vasantha P. V. Rupasinghe ${ }^{2}$, and Chung-Ja C. Jackson ${ }^{3}$ \\ ${ }^{1}$ Department of Plant Agriculture, University of Guelph, Guelph, ON N1G 2W1, Canada \\ ${ }^{2}$ Department of Environmental Sciences, Nova Scotia Agricultural College, Truro, NS B2N 5E3, Canada \\ ${ }^{3}$ Formerly with Guelph Center for Functional Foods, Laboratory Services, University of Guelph, Guelph, ON N1H 8J7, \\ Canada
}

Leaf characteristics of mature 2, 3 and 4-year-old North American ginseng (Panax quinquefolius L.) leaves on fruiting and nonfruiting (NF) plants were studied. Leaflets of the 2-year-old plants had the lowest fresh and dry weight, area, volume and internal gas volume. Inflorescence removal in 3-year-old plants did not affect leaf characteristics or ginsenoside concentration but in 4-yearold plants it increased leaf fresh (38.6\%) and dry (43.9\%) weight, leaf area (29.1\%), specific leaf mass (11.4\%), leaf volume (43.1\%), and leaf thickness (12.1\%), and decreased leaf water content (6.2\%). Cultivated ginseng, although an understorey plant, had the specific leaf mass, $35.6 \mathrm{~g} \mathrm{~m}^{-2}$ (range, 36 to $39 \mathrm{~g} \mathrm{~m}^{-2}$ ) and a chlorophyll a/b ratio of 2.40 to 2.61, both suggesting the ability to perform like a sunny habitat plant. Also, specific leaf mass of $35.6 \mathrm{~g} \mathrm{~m}^{-2}$ is similar to that reported for perennial plants, $36.8 \mathrm{~g} \mathrm{~m}^{-2}$, rather than that for annuals, $30.9 \mathrm{~g} \mathrm{~m}^{-2}$.

Keywords: Dry weight, Inflorescence removal, Panax quinquefolius, Shade plant

\section{INTRODUCTION}

North American ginseng (P. quinquefolius L.) is an understorey herbaceous perennial which is native to the hardwood forests of north-eastern North America. In cultivation of ginseng the environmental regime of the hardwood forest is simulated by erection of shade and addition of mulches [1-3]. The ginseng plant is well adapted to its artificial shade environment provided that certain light requirements are maintained. For instance, during the growing season only one set of leaves is produced [4] and root growth (economic yield) [5] depends solely on these leaves. If these leaves are exposed to full rather than the usual $25 \%$ of sunlight photoinhibition and chlorophyll bleaching take place rapidly $[2,6,7]$.
Ginseng leaves growing in a shaded field environment, or in the forest understorey, are likely adapted to low light conditions [8]. For instance, such leaves have low photosynthetic rates [9], may contain more chlorophyll per reaction center and have a smaller chlorophyll a/b ratio [10], and may be thinner than leaves growing in full sun [11].

Proctor and Bailey [2] reviewed leaf and leaflet complement in ginseng of different ages. However, apart from leaflet stomata density, they did not discuss morphological characteristics. Leaf area of ginseng has been reported [12] but internal structure has not although it has implications for leaf photosynthesis. Manual inflores-

(c) This is an Open Access article distributed under the terms of the Creative Commons Attribution Non-Commercial License (http://creativecommons.org/licenses/by-nc/3.0/) which permits unrestricted non-commercial use, distribution, and reproduction in any medium, provided the original work is properly cited.

Received 29 Oct. 2010, Revised 22 Mar. 2011, Accepted 23 Mar. 2011

*Corresponding author

E-mail: jtprocto@uoguelph.ca

Tel: +1-519-824-4120 (ext. 53446), Fax: +1-519-767-0755. 
cence removal increases ginseng root yield by $26 \%$ [13] but nothing is known about the effect of this removal on leaf physical properties. We therefore addressed these characters in these studies.

The medicinal value of ginseng is attributed mostly to a group of triterpene saponins known as ginsenosides [14]. Over 30 ginsenosides have been isolated from roots, leaves, stems, flower buds and berries have the highest concentration in leaves [15]. Ginsenoside content varies depending on plant part and age [15], fertility level [16,17], harvest date [18] and light levels [19]. The effect of the established practise of manual inflorescence removal to increase root yield [13] on ginsenoside content has not been reported so was investigated in this study.

In summary, this study was undertaken to compare morphological characteristics of ginseng leaves of different ages, and to study the effect of inflorescence removal on these characteristics and on ginsenoside content.

\section{MATERIALS AND METHODS}

\section{Plant material and physical measurements}

Leaves from 2-, 3-, and 4-year-old plants, which had been established at a seeding rate of $90 \mathrm{~kg} \cdot \mathrm{ha}^{-1}$ and grown using standard North American techniques and cultural measurements [20], were collected in mid-season [4]. For the purposes of this experiment, five leaf categories were established: leaves on 2-year-old non-fruiting (NF) plants; leaves on 3-year-old fruiting (F) and NF plants; and leaves on 4-year-old $\mathrm{F}$ and NF plants. Leaves were harvested from plants in a completely randomized design under sunny conditions between 1,000 and 1,200 HR. Three harvests were made, approximately one week apart. As leaves were harvested they were sealed in plastic bags which were placed in ice-cooled containers for transportation from the field to the laboratory.

In the laboratory the leaves were separated into their leaflets. Two-year-old plants had two leaves each with 3 to 5 leaflets, rarely 4 leaflets; three- and four-year-old plants had 3 and 4 leaves, respectively, each with 3 to 5 leaflets $[4,12]$. The central leaflet of the 3 or 5 leaflets was used in all measurements as it was found representative of the compound leaf. Twelve leaflet characteristics were measured (Table 1). Fresh weight (FW) measurements, after petioles were removed, were recorded and leaf area was measured using a LI-3000 area meter (LICOR, Lincoln, NE, USA) fitted with a LI-3053 transparent belt accessory. Leaf chlorophyll a and b were determined by extraction using $1.5 \mathrm{~cm}$ diameter tissue discs in $85 \%$ boiling ethanol [21] and measuring absorption on a Milton Roy Spectronic 1001 Plus spectrophotometer (Rochester, NY, USA).

To determine total leaf volume and internal gas volume, a technique based on Archimedes' principle [22] measured the buoyant force acting on leaves submerged in liquid. After a leaf was weighed in air (FW), it was dipped in a $0.05 \%(\mathrm{v} / \mathrm{v})$ aqueous solution of the surfactant, Triton X-100, which prevents air bubbles from adhering to the leaf surface when submerged in water and avoids an overestimation of leaf volume. The leaf weight was then determined in distilled water $\left(\rho_{\text {water }}=1.0 \mathrm{~g} \cdot \mathrm{cm}^{3}\right)$ by suspending the leaf from a wire and leaf clamp connected to a built-in hook on the bottom of a pretared pan balance (PE 360; Mettler Instrument Corp., Hightstown, NJ, USA). Finally the leaf was placed in a desiccator, totally submerged in a Triton X-100 $0.05 \%(\mathrm{v} / \mathrm{v})$ solution. A vacuum of approx. $500 \mathrm{~mm}$ mercury was applied for 30 seconds and released three times while the tissue was being agitated. The infiltrated leaf was then reweighed submerged in water as described above. Following these procedures, leaves were placed in an oven at $80^{\circ} \mathrm{C}$ and dried to constant weight. Leaf water content (LWC) on a dry weight basis was calculated. Leaf thickness was calculated from area and volume data [22].

\section{Ginsenoside extraction, purification and analysis}

Dried root and leaf samples from flowering (F) and non-flowering (NF) plants were ground and screened to obtain homogeneous samples. The inflorescences were removed during bloom either manually or by a spray of Ethephon at $1,500 \mathrm{mg} \mathrm{L}^{-1}$ as outlined by Fiebig et al. [23]. The method for ginsenoside extraction, purification and quantification was similar to those described previously $[15,24]$. This method allows detection of the six major ginsenosides, $\mathrm{Rb}_{1}, \mathrm{Rb}_{2}, \mathrm{Rc}, \mathrm{Rd}, \mathrm{Re}$ and $\mathrm{Rg}_{1}$, and the oleanolic ginsenoside Ro.

Data analyses were carried out using the general linear model procedure of the SAS (SAS Institute Inc., Cary, $\mathrm{NC}, \mathrm{USA}$ ) at a probability level of 0.05 . In the absence of significant interactions and main effects, data were pooled for analysis.

There was no significant effect of harvest date so data were pooled for analysis.

\section{RESULTS AND DISCUSSION}

\section{Leaflet age}

Leaflets of the 2-year-old plants had the lowest fresh and dry weight, area,volume and internal gas volume (Table 1). In this regard, two-year-old plants are devel- 
Table 1. Leaflet characteristics of non-flowering (NF) and flowering (F) 2, 3, and 4 year-old North American ginseng plants

\begin{tabular}{|c|c|c|c|c|c|}
\hline \multirow{2}{*}{ Leaflet characteristics ${ }^{1)}$} & \multicolumn{5}{|c|}{ Age of plant and flowering status } \\
\hline & $2 \mathrm{yr} \mathrm{NF}$ & $3 \mathrm{yrF}$ & $3 \mathrm{yr} \mathrm{NF}$ & $4 \mathrm{yr} \mathrm{F}$ & 4 yr NF \\
\hline Fresh wt (g) & $2.22(\mathrm{c})^{2)}$ & 3.76 (b) & 4.09 (b) & 3.76 (b) & $5.31(\mathrm{a})$ \\
\hline Dry wt (g) & $0.56(\mathrm{c})$ & 0.87 (b) & 0.94 (b) & 0.89 (b) & 1.29 (a) \\
\hline Leaf water content $\left(\mathrm{g} \mathrm{g}^{-1}\right)$ & 0.75 (b) & 0.77 (a) & 0.77 (a) & 0.76 (a) & $0.75(b)$ \\
\hline Specific leaf mass $\left(\mathrm{g} \mathrm{m}^{-2}\right)$ & $36(b)$ & $34(b)$ & 34 (b) & 35 (b) & 39 (a) \\
\hline Volume $\left(\mathrm{mm}^{3}\right)$ & $1727(\mathrm{c})$ & 2971 (b) & 3197 (b) & 3031 (b) & 4339 (a) \\
\hline Density $\left(\mathrm{mg} \mathrm{mm}^{-3}\right)$ & 1.29 (a) & 1.26 (a) & 1.40 (a) & 1.24 (a) & 1.20 (a) \\
\hline Thickness $(\mu \mathrm{m})$ & 112 (b) & $116(b)$ & 113 (b) & 116 (b) & 130 (a) \\
\hline Internal gas volume $\left(\mathrm{mm}^{3}\right)$ & 232 (b) & 500 (a) & 620 (a) & 532 (a) & 656 (a) \\
\hline Total chlorophyll $\left(\mu \mathrm{g} \mathrm{cm}^{-2}\right)$ & $29.0(b)$ & 29.6 (b) & $27.2(b)$ & 33.2 (a) & 33.4 (a) \\
\hline Chlorophyll a $\left(\mu \mathrm{g} \mathrm{cm}^{-2}\right)$ & $20.8(b)$ & 20.9 (b) & $19.6(b)$ & 23.8 (a) & 24.1 (a) \\
\hline Chlorophyll b $\left(\mu \mathrm{g} \mathrm{cm}^{-2}\right)$ & 8.2 (b) & 8.7 (b) & 7.8 (b) & 9.1 (a) & 9.4 (a) \\
\hline Chlorophyll a/b ratio & 2.54 (b) & 2.40 (a) & 2.58 (b) & $2.61(\mathrm{~b})$ & $2.56(\mathrm{~b})$ \\
\hline
\end{tabular}

${ }^{11}$ Each value is a mean for 20 leaflets.

${ }^{2}$ Mean separation within leaflet characteristics by Duncan's multiple range test at $p=0.05$.

opmentally transitory in that their leaves have progressed from the small $\left(15.4 \mathrm{~cm}^{2}\right)$ (Table 1) trifoliate leaf (stage 109) [4], to the larger $\left(26.4 \mathrm{~cm}^{2}\right)$ (Table 1) 3- to 5-foliate leaves (stage 119) [4]. The 2-year-old leaflets were the smallest and had the lowest dry weight; dry matter of these leaflets was $25 \%$ which, expressed as LWC, was $0.75 \mathrm{~g} \mathrm{~g}^{-1}$ (Table 1). Generally LWC varied little with age ranging from 0.75 to $0.77 \mathrm{~g} \mathrm{~g}^{-1}$ (Table 1).

\section{Chlorophyll content}

Total chlorophyll content was similar in 2- and 3-yearold plants (range, 27.2 to $29 \mu \mathrm{g} \mathrm{m}^{-2}$ ) and lower than in 4-year-old plants (mean, $33.3 \mu \mathrm{g} \mathrm{m}^{-2}$ ) (Table 1). The higher chlorophyll content of the 4-year-old plants may be due to the greater leaf thickness and a tendency to larger internal gas volume as chloroplasts congregate in a single layer on the cell wall/air interface. The chlorophyll a/b ratio ranged from 2.40 to 2.61 (Table 1) which is higher than that of three shade species, Cissus rhombifolia Planch, Fatsia japonica Decne \& Planch, Philodendrom scandens Koch \& Sell, mean of 1.41 [25], but similar for shade leaves of hazelnut (Corylus avellana L.) (-2.50) growing at 60\% shade [26]. Apple leaves growing in full sun had a chlorophyll $\mathrm{a} / \mathrm{b}$ ratio of 2.46 to 2.80 [27]. The lower chlorophyll $\mathrm{a} / \mathrm{b}$ ratios are thought to be an adaptation to enhance absorption of limited red light in a shade environment and to maintain the energy balance between photosynthetic system (PS)II and PSI $[28,29]$.

\section{Inflorescence removal effects}

Inflorescence removal in 3-year-old plants had no significant effect on leaflet characteristics (Table 1) although there was a trend towards increases in, for example, fresh and dry weight, leaf area and volume. In contrast, in fouryear-old plants, inflorescence removal increased leaflet FW (38.6\%) and dry weight (43.9\%), leaf area (29.1\%), specific leaflet weight (11.4\%), leaflet volume (43.1\%), and thickness (12.1\%) and decreased leaflet water content $(6.2 \%)$ (Table 1).

\section{Specific leaflet mass}

Our specific leaf mass (SLM) data for the understorey herbaceous ginseng cultivated under artifical shade gave a mean of $35.6 \mathrm{~g} \mathrm{~m}^{-2}$ (range, 34 to $39 \mathrm{~g} \mathrm{~m}^{-2}$ ) (Table 1). Pyankov et al. [30] reported a mean SLM of $36.2 \mathrm{~g}$ $\mathrm{m}^{-2}$ for herbaceous species growing in open sunny habitats in south-eastern Canada; understorey herbaceous plants had a mean SLM of $22.5 \mathrm{~g} \mathrm{~m}^{-2}$ (range, 16.9 to $30.5 \mathrm{~g} \mathrm{~m}^{-2}$ ). Therefore, cultivated ginseng has the SLM of a sunny habitat plant rather than that of a shaded environment. Our earlier work with forest-grown ginseng [1] showed that sunfleck duration best modeled shoot and root dry weight suggesting that it uses direct sunlight and is performing as a sunny habitat plant. This also complements the data for chlorophyll $\mathrm{a} / \mathrm{b}$ ratios reported above.

Garnier and Laurent [31] showed that the SLM was greater in perennial grass species than in annual species (36.8 vs. $30.9 \mathrm{~g} \mathrm{~m}^{-2}$, respectively). A mean SLM of 35.6 $\mathrm{g} \mathrm{m}^{-2}$ for ginseng (Table 1) places it in the perennial plant 
Table 2. Linear regression analyses data showing the statistical dependencies of specific leaf mass (SLM, $\mathrm{gm}^{-2}$, dependent variable) and leaf thickness ( $\mu \mathrm{m}$, independent variable) for North American ginseng leaves of different ages on non-flowering (NF) or flowering (F), $n=20$, plants

\begin{tabular}{cccccc}
\hline Plant age, NF or F & $\begin{array}{c}\text { Range of values, } \\
\text { SLM }\left(\mathrm{gm}^{-2}\right)\end{array}$ & $\begin{array}{c}\text { Range of values, } \\
\text { leaf thickness }(\mu \mathrm{m})\end{array}$ & Intercept & Slope & $R^{2}$ \\
\hline 2 yr (NF) & $28.3-48.3$ & $87.4-136.4$ & 2.5 & 0.30 & 0.66 \\
3 yr (NF) & $22.7-43.4$ & $90.7-147.4$ & 6.3 & 0.23 & 0.34 \\
3 yr (F) & $24.7-44.2$ & $89.1-133.3$ & 8.4 & 0.22 & 0.29 \\
4 yr (NF) & $33.7-48.3$ & $105.5-160.0$ & 9.3 & 0.23 & 0.58 \\
4 yr (F) & $25.2-41.8$ & $90.0-129.5$ & -2.3 & 0.31 & 0.58 \\
All ages and treatments $(n=100)$ & $22.7-48.3$ & $87.4-160.0$ & 6.1 & 0.25 & 0.47 \\
\hline
\end{tabular}

category. Ginseng is an herbaceous perennial [4] and in all three plant ages (2,3 and 4 years) (Table 1$)$ the leaves had the SLM of a perennial, not of an annual. Specific leaflet mass of ginseng was similar for the three leaf ages (mean, $35.6 \mathrm{gm}^{-2}$ ) (Table 1), the only significant exception was the SLM of $39 \mathrm{~g} \mathrm{~m}^{-2}$ for leaves on non-flowering 4-year-old plants. The higher SLM in 4-year-old NF vs. $\mathrm{F}$ plants is consistent with the finding of greater biomass allocation (34.7\%) [5] to the roots of such plants.

\section{Specific leaf mass and leaf thickness}

SLM increased with leaflet thickness over a wide range of thicknesses (Table 2). For instance, in twoyear-old ginseng leaflet thickness ranged from 87.4 to $136.6 \mu \mathrm{m}$ while in four-year-old non-flowering plants it ranged from 105.5 to $151.6 \mu \mathrm{m}$. These thickness values are much lower than those for sun grown leaves of apple which were 150 to $250 \mu \mathrm{m}$ [27] but similar to the ornamental shade species, C. rhombifolia (grape or oakleaf ivy) with a value of $114 \mu \mathrm{m}$ [25]. C. rhombiafolia, although a shade species, is relatively light tolerant as is ginseng when exposed to short-term direct sunlight as in sunflecks [1].

The accompanying regression analyses data for SLM and leaflet thickness (Table 2) show that the coefficient of determination $\left(R^{2}\right)$, with the exception of the three-yearold leaflets, leaf thickness accounted for 47\% (all data) and 66\% (two-year-old leaflets) of the variation in SLM. The reason for the variation in the data for the three-yearold leaflets is unknown.

\section{Ginseng leaf features}

Specific leaf mass, lamina thickness, stomatal density, light compensation point, dark respiration, net photosynthesis, stomatal conductance and chlorophyll $\mathrm{a} / \mathrm{b}$ ratio for shade obligatory ginseng leaflets were similar to those of other shade plants [25] but lower than reported values for sun-grown leaves of a range of plants (Table 3). These adaptations of ginseng are a reflection of its ability to cope with the lower end of the light gradient, i.e. about $20 \%$ to $30 \%$ of full sunlight $[1,6,10]$.

The ability of plants to survive and grow at low light levels is complex [32]. A simple field measure of shade tolerance known as the whole-plant light compensation point (WPLCP) has been developed [33]. Dark respiration $\left(\mathrm{R}_{\mathrm{d}}\right)$ is the single best predictor of WPLCP [33] (Table 3 ) and is correlated with leaf-level light compensation (LLCP). Our values for $\mathrm{R}_{\mathrm{d}}$ and LLCP in Table 3 agree well with those of Baltzer and Thomas [33], for 20 tree species saplings grown in shade. For example, LLCP for ginseng is $5 \mu \mathrm{mol} \mathrm{m} \mathrm{m}^{-2} \mathrm{~s}^{-1}$ (Table 3) while for the 20 tree saplings it ranged from 3.6 to $5.3 \mu \mathrm{mol} \mathrm{m}^{-2} \mathrm{~s}^{-1}$ [33] (Table 3 ). This suggests that studies of these traits may provide a better understanding of the shade tolerance of a wide range of plants.

One of the main leaf features of ginseng as an obligate shade plant, whose natural habitat is the understory of temperate deciduous hardwood forests, is that it is sensitive to light [1]. It is photoinhibited with associated tissue damage at about $500 \mu \mathrm{mol} \mathrm{m}^{-2} \mathrm{~s}^{-1}$ (Table 3) whereas similar damage in non-obligatory shade plants grown in full sun is at about 2,000 $\mu \mathrm{mol} \mathrm{m}^{-2} \mathrm{~s}^{-1}$ [34]. Sun leaves have a high capacity for photosynthetic electron transport and for photoprotective thermal energy dissipation; ginseng shade-growing leaves have a low capacity for photosynthetic electron transport and for dissipation of excess excitation energy. The specific nature of this response of ginseng leaves remains to be elucidated [35].

\section{Inflorescence removal and ginsenoside content}

Inflorescence removal by hand or by an ethephon spray did not influence the total ginsenoside concentration in either roots or leaves (Table 4). The ginsenoside concentrations reported here for roots and leaves are similar to those reported by Jackson et al. [15] and Li and Mazza [16]. There was considerable variation in the 
Table 3. Plant features associated with the shade-cultivated North American ginseng compared to sun-grown plants

\begin{tabular}{lcr}
\hline \multicolumn{1}{c}{ Feature } & Expected value for shade-cultivated ginseng & Expected value for sun-grown species \\
\hline Leaf anatomy and morphology & & $79[39]$ \\
Specific leaf mass per area $\left(\mathrm{g} \mathrm{m}^{-2}\right)$ & $34-39[$ Table 1] & $173-183[31]$ \\
Lamina thickness $(\mu \mathrm{m})$ & $112-130[$ Table 1] & $40-300[40]$ \\
Stomatal density $\left(\mathrm{mm}^{-2}\right)$ & $35-136[2]$ & $8-16[40]$ \\
Leaf physiology and biochemistry & & $0.22[41]$ \\
Light compensation point $\left(\mu \mathrm{mol} \mathrm{m}^{-2} \mathrm{~s}^{-1}\right)$ & $5[9]$ & $1.60[41]$ \\
Dark respiration rate $\left(\mathrm{gCO}_{2} \mathrm{~m}^{-2} \mathrm{~h}^{-1}\right)$ & $0.03[9]$ & Not comparable \\
Net photosynthetic rate $\left(\mathrm{gCO}_{2} \mathrm{~m}^{-2} \mathrm{~h}^{-1}\right)$ & $0.39[9]$ & $2000[34]$ \\
Sunfleck use efficiency & High [1] & $2-10[42]$ \\
Sensitivity to photoinhibition $\left(\mu \mathrm{mol} \mathrm{m}^{-2} \mathrm{~s}^{-1}\right)$ & $500[$ Proctor, unpublished] & $40.0-53.0[28]$ \\
Stomatal conductance $\left(\mathrm{mm} \mathrm{s}^{-1}\right)$ & $1.0-2.4[2]$ & $3.0[40]$ \\
Chlorophyll concentration $\left(\mu \mathrm{g} \mathrm{cm}^{-2}\right)$ & $29.0-33.4[$ Table 1] \\
Chlorophyll a/b ratio & $2.40-2.61[$ Table 1] & \\
\hline
\end{tabular}

Data presented are from the experiments reported herein, or from published sources listed in the [References].

Table 4. Total ginsenoside content ( $\mathrm{mg} \mathrm{g}^{-1}$ dry wt) of 3-year-old North American ginseng roots and leaves of plants where the inflorescences remained on the plant (control), removed during bloom by hand, or removed during bloom by an ethephon spray at $1,500 \mathrm{mg} \mathrm{L}^{-1}$

\begin{tabular}{lcc}
\hline \multirow{2}{*}{ Treatment } & \multicolumn{2}{c}{ Total ginsenosides $\left(\mathrm{mg} \mathrm{g}^{-1}\right)$} \\
\cline { 2 - 3 } & Roots $\pm \mathrm{SD}$ & Leaves $\pm \mathrm{SD}$ \\
\hline Control, inflorescence retained & $70.8 \pm 10.9$ & $61.8 \pm 12.3$ \\
Inflorescence removed by hand & $69.8 \pm 4.6$ & $62.6 \pm 6.7$ \\
Inflorescence removed by ethephon spray & $62.6 \pm 7.7$ & $66.1 \pm 10.3$ \\
Mean & $67.7 \pm 8.4$ & $63.5 \pm 9.5$ \\
\hline
\end{tabular}

ginsenoside content which is reflected in the large standard deviation values in Table 4. For instance, the total leaf ginsenosides were $61.8 \pm 12.3 \mathrm{mg} \mathrm{g}^{-1}$. Similar large standard deviations for total ginsenosides have been reported by Smith et al. [36] and Starratt et al. [37] and likely reflect the genetic variability of the crop which is essentially a wild species.

\section{Summary and conclusions}

Considerable progress has been made worldwide to design ginseng gardens for optimum light interception for use in photosynthesis and dry matter production as the dried root is the economic product. The next stage is to integrate measurements of light fluxes at the leaf level, and within plant tissues, with the physiological processes that depend on light.

The examination of the relationships between leaf anatomy and morphology, as reported here, light gradients, and photosynthetic performance at the whole leaf level, and within the leaf, are particularly important. For instance, maximum photosynthesis is correlated with the amounts of compounds that determine photosynthetic capacity. These are located in the greater number of chloroplasts per area and the larger stroma volume and stromaexposed thylakoids in chloroplasts [38]. Such studies will advance our understanding of leaf structure and function. These in turn will help in ginseng garden design and provide fundamental information about photosynthetic responses to stressful changes induced by fluctuating light and temperature.

\section{ACKNOWLEDGEMENTS}

We are indebted to Dean Louttit and Heather Proctor for technical assistance.

\section{REFERENCES}

1. Fournier AR, Gosselin A, Proctor JT, Gauthier L, Khanizadeh S, Dorais M. Relationship between understory light and growth of forest-grown American ginseng (Panax quinquefolius L.). J Am Soc Hort Sci 2004;129:425-432.

2. Proctor JT, Bailey WG. Ginseng: industry, botany, and culture. Hort Rev 1987;9:187-236.

3. Stathers RJ, Bailey WG. Energy receipt and partitioning in a ginseng shade canopy and mulch environment. Agric For Meteorol 1986;37:1-14.

4. Proctor JT, Dorais M, Bleiholder H, Willis A, Hack H, Meier V. Phenological growth stages of North American ginseng (Panax quinquefolius). Ann Appl Biol 
2003;143:311-317.

5. Proctor JT. Source-sink relations in North American ginseng seedlings as influenced by leaflet removal. J Ginseng Res 2008;32:337-340.

6. Lee SS, Proctor JT, Choi KT. Influence of monochromatic light on photosynthesis and leaf bleaching in Panax species. J Ginseng Res 1999;23:1-7.

7. Parmenter GA, Littlejohn RP. The effect of irradiance during leaf development on photoinhibition in Panax ginseng C. A. Meyer. J Ginseng Res 1998;22:102-113.

8. Lambers $H$, Poorter H. Inherent variation in growth rate between higher plants: a search for physiological causes and ecological consequences. In: Begon M, Fitter A. Advances in ecological research. Vol. 23. San Diego: Academic Press, 1992. p.187-261.

9. Proctor JT, Palmer JW, Follett JM. Growth, dry matter partitioning and photosynthesis in North American ginseng seedlings. J Ginseng Res 2010;34:175-182.

10. Fournier AR, Proctor JT, Khanizadeh S, Gosselin A, Dorais $\mathrm{M}$. Acclimation of maximum quantum yield of PSII and photosynthetic pigments of Panax quinquefolius L. to understory light. J Ginseng Res 2008;32:347-356.

11. Niinemets U. Components of leaf dry mass per area: thickness and density. Alter leaf photosynthetic capacity in reverse directions in woody plants. New Phytol 1999; 144:35-47.

12. Hughes BR, Proctor JT. Estimation of leaflet, leaf, and total leaf area of Panax quinquefolius L. using linear measurements. J Am Soc Hort Sci 1981;106:167-170.

13. Proctor JT, Percival D, Louttit D. Inflorescence removal affects root yield of American ginseng. HortScience 1999;34:82-84.

14. Awang DV, Li MZ. The pharmacologically active constituents of white and red ginseng root. HerbalGram 2008;80:38-49.

15. Jackson CJ, Dini JP, Lavandier C, Faulkner HP, Rupasinghe HP, Proctor JT. Ginsenoside content of North American ginseng (Panax quinquefolius L. Araliaceae) in relation to plant development and growing locations. J Ginseng Res 2003;27:135-140.

16. Li TS, Mazza G. Correlations between leaf and soil mineral concentrations and ginsenoside contents in American ginseng. HortScience 1999;34:85-87.

17. Konsler TR, Zito SW, Shelton JE, Staba EJ. Lime and phosphorus effects on American ginseng: II. Root and leaf ginsenoside content and their relationship. J Am Soc Hort Sci 1990;115:575-580.

18. Reynolds LB. Effects of drying on chemical and physical characteristics of American ginseng (Panax quinquefolius L.). J Herbs Spices Med Plants 1998;6:9-21.
19. Fournier AR, Proctor JT, Gauthier L, Khanizadeh S, Belanger A, Gosselin A, Dorais M. Understory light and root ginsenosides in forest-grown Panax quinquefolius. Phytochemistry 2003;63:777-782.

20. Proctor JT. Ginseng: old crop, new directions. In: Janick $\mathrm{J}$, ed. Proceedings of the third national symposium: new crops, new opportunities, new technologies. Alexandria (VA): American Society for Horticultural Science Press, 1996. p.565-577.

21. Wintermans JF, de Mots A. Spectrophotometric characteristics of chlorophylls $\mathrm{a}$ and $\mathrm{b}$ and their pheophytins in ethanol. Biochim Biophys Acta 1965;109:448-453.

22. Raskin I. A method for measuring leaf volume, density, thickness, and internal gas volume. HortScience 1983;18:698-699.

23. Fiebig AE, Proctor JT, Murr DP, Reeleder RD. Flower abscission and induction in North American ginseng with Ethephon. HortScience 2005;40:138-141.

24. Court WA, Hendel JG, Elmi J. Reversed-phase highperformance liquid chromatography determination of ginsenosides in Panax quinquefolium. J Chromatogr A 1996;755:11-17.

25. Araus JL, Alegre L, Tapia L, Calafell R, Serret MD. Relationships between photosynthetic capacity and leaf structure in several shade plants. Am J Bot 1986;73:17601770.

26. Hampson CR, Azarenko AN, Potter JR. Photosynthetic rate, flowering, and yield component alteration in hazelnut in response to different light environments. J Am Soc Hort Sci 1996;121:1103-1111.

27. Schechter I, Proctor JT, Elfving DC. Morphological differences among apple leaf types. HortScience 1992;27: 101-103.

28. Boardman NK. Comparative photosynthesis of sun and shade plants. Annu Rev Plant Physiol 1977;28:355-377.

29. Yin ZH, Johnson GN. Photosynthetic acclimation of higher plants to growth in fluctuating light environments. Photosynth Res 2000;63:97-107.

30. Pyankov VI, Kondratchuk AV, Shipley B. Leaf structure and specific leaf mass: the alpine desert plants of the Eastern Pamirs, Tadjikistan. New Phytol 1999;143:131-142.

31. Garnier E, Laurent G. Leaf anatomy, specific mass and water content in congeneric annual and perennial grass species. New Phytol 1994;128:725-736.

32. Vallardes F, Niinemets U. Shade tolerance, a key plant feature of complex nature and consequences. Annu Rev Ecol Evol Syst 2008;39:237-257.

33. Baltzer JL, Thomas SC. Determinants of whole-plant light requirements in Bornean rain forest tree saplings. $\mathrm{J}$ Ecol 2007;95:1208-1221. 
34. Demmig-Adams B, Adams WW III. Photoprotection and other responses of plants to high light stress. Annu Rev Plant Physiol Plant Mol Biol 1992;43:599-626.

35. Miskell JA, Parmenter G, Eaton-Rye JJ. Decreased Hill reaction rates and slow turnover of transitory starch in the obligate shade plant Panax quinquefolius L. (American ginseng). Planta 2002;215:969-979.

36. Smith RG, Caswell D, Carriere A, Zielke B. Variation in the ginsenoside content of American ginseng, Panax quinquefolius L., roots. Can J Bot 1996;74:1616-1620.

37. Starratt AN, Hendel JG, Reeleder RD. Leaves of North American ginseng, Panax quinquefolius L.: a renewable source of certain ginsenosides. Can J Plant Sci 2001;81: 65-67.
38. Evans JR. Photosynthesis and nitrogen relationships in leaves of $\mathrm{C}_{3}$ plants. Oecologia 1989;78:9-19.

39. Hallik L, Niinemets U, Wright IJ. Are species shade and drought tolerance reflected in leaf-level structural and functional differentiation in Northern Hemisphere temperate woody flora? New Phytol 2009; 184:257-274.

40. Nobel PS. Physicochemical and environmental plant physiology. San Diego: Academic Press, 1991.

41. Gratani L, Varone L, Bonito A. Environmental induced variations in leaf dark respiration and net photosynthesis of Quercus ilex L. Photosynthetica 2007;45:633-636.

42. Korner C, Scheel JA, Bauer H. Maximum leaf diffusive conductance in vascular plants. Photosynthetica 1979;13:45-82. 